J. Range Manage.

48:198-201 May 1995

\title{
Forage intake by beef steers grazing winter wheat with varied herbage allowances
}

\author{
LARRY A. REDMON, F. TED MCCOLLUM III, GERALD W. HORN, MATTHEW D. \\ CRAVEY, STACEY A. GUNTER, PAUL A. BECK, JUAN M. MIERES, AND ROBERTO SAN \\ JULIAN
}

Authors are assistant professor, Agronomy Department, professor, professor, and former graduate students, Animal Science Department, Oklahoma State University, Stillwater 74074.

\begin{abstract}
Two grazing trials were conducted in separate years on a 5.86 ha winter wheat (Triticum aestivum var. Chisholm) pasture divided into 10 experimental paddocks. Paddocks were differentially grazed with beef steers to produce an array of different herbage mass levels, expressed as kg dry matter (DM)/ha. Each experimental paddock was then continuously stocked with 3 heef steers during each 7-day forage intake trial. Daily forage intake, expressed as $\mathrm{kg}$ organic matter (OM)/100 kg body weight (BW), was estimated from fecal output $\left(\mathrm{Cr}_{2} \mathrm{O}_{3}\right.$ dilution) of the beef steers and in vitro organic matter disappearance of esophageal masticate collected from each paddock. Estimated daily gain was calculated from forage intake and net energy values calculated from organic matter disappearance data. Forage intake, organic matter disappearance, and estimated daily gain were related to daily herbage allowance, expressed as $\mathrm{kg} \mathrm{DM} 100 \mathrm{~kg} \mathrm{BW}^{-1} \mathrm{day}^{-1}$, and herbage mass utilizing a quadratic equation with a plateau function. As herbage allowance increased, organic matter disappearance improved $(Y=62.18+1.08$ herbage allowance -.022 herbage allowance'; $\mathrm{r}^{2}=.64, \mathrm{MSE}=5.06$ ) as did forage intake (Y $=1.3+.12$ herbage allowance -.003 herbage allowance ${ }^{2} ; r^{2}=.52$, MSE $=.07)$, and estimated daily gain $(\mathrm{Y}=-.059+.12$ herbage allowance -.003 herbage allowance ${ }^{2} ; r^{2}=.59, \mathrm{MSE}=.07$ ). Plateaus were achieved at herbage allowance between 20 to $24 \mathrm{~kg}$ DM1 $100 \mathrm{~kg} \mathrm{BW}^{-1}$ day $^{-1}$. Results of this study indicate forage intake and estimated daily gain declined severely as herbage

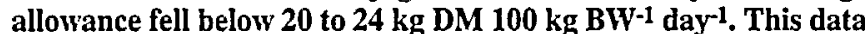
may provide a threshold herbage allowance for initiation of energy supplementation programs for growing cattle on wheat pasture.
\end{abstract}

Key words: cattle, intake, small grains, Triticum aestivum

Annual forage species such as wheat (Triticum aestivum) and rye (Secale cereale) are the primary cool-season forages grazed by growing beef cattle in the southern Great Plains region of the

This project was approved for publication by the Director, Oklahoma Agricultural Experiment Station. This re earch was supported under project $S$ 2083. This material is based upon work supported by the Cooperative State Research Service, USDA, under Agreement No. 89-34198-4288.

Manuscript accepted 8 Oct. 1994.
United States. A problem frequently encountered by producers in the region during winter months is limited herbage mass for grazing livestock. Herbage mass is a function of such factors as planting date, seeding rate, variety, precipitation, temperature, and stocking rate. Interactions between cultural and management practices and environmental influences may serve to reduce herbage mass during any year. However, stocking rate may be the most important variable that can be directly manipulated by the producer.

Better understanding of the impact of limited herbage mass on forage and nutrient intake, thus animal performance, would aid in the development of supplemental feeding programs designed to economically maintain a desirable level of gain in growing cattle. Hodgson (1990), who has studied perennial ryegrass (Lolium perenne L.) and perennial rycgrass/clover (Trifolium spp.) swards, stated herbage intake and animal performance would increase with increased herbage allowance, expressed as kg dry matter (DM) $100 \mathrm{~kg}$ body weight $(\mathrm{BW})^{-1}$ day $^{-1}$, but plateau at a herbage allowance of about 10 to $12 \%$ of body weight. Ellis et al. (1984) studied annual ryegrass (Lolium multiflorum Lam.) intake as paddocks were progressively defoliated. Daily intake declined as herbage allowance was reduced below $30 \mathrm{~kg} \mathrm{DM} / 100 \mathrm{~kg} \mathrm{BW}$. However, fecal output remained constant as herbage allowance decreased from 70 to $10 \mathrm{~kg} \mathrm{DM} / 100 \mathrm{~kg} \mathrm{BW}$, which indicated that the reduction in forage intake was due to reduced digestibility of the diet rather than the inability to prehend forage. Little is known, however, about the relationship between herbage allowance of wheat forage and growing cattle. This study was designed to determine the relationship between herbage allowance and in vitro organic matter (OM) disappearance in diets of cattle grazing wheat forage, the relationship between herbage allowance and forage intake ( $\mathrm{kg} \mathrm{OM} / 100 \mathrm{~kg} \mathrm{BW})$, and the relationship between herbage allowance and estimated daily gain of growing beef cattle grazing wheat forage.

\section{Materials and Methods}

The study was conducted at a facility approximately $5.6 \mathrm{~km}$ west of the Oklahoma State University main campus at Stillwater. In February 1991, and January 1992, a 5.8-ha paddock 
of winter wheat forage (Triticum aestivum var. Chisholm) was subdivided into 8 paddocks of 0.4 ha each and 2 paddocks of 0.8 and 1.8 ha $(n=10)$, respectively. Paddocks were differentially grazed with beef steers to produce a range of herbage mass values in each of the paddocks. Differences in herbage mass were established initially by ocular estimate but subsequently determined by hand-clipping forage samples. We clipped forage from within a $0.25-\mathrm{m}^{2}$ sample frame to ground level in each paddock and dried the samples to a constant weight in a forced-air oven at $60^{\circ} \mathrm{C}$. We then weighed the dried samples to the nearest $0.1 \mathrm{~g}$ to determine the initial herbage mass for each paddock before grazing trial initiation. There were no targeted ranges of herbage mass intended; the intent being to establish an array of herbage mass levels typical of those encountered under typical production systems. The 2 larger paddocks allowed for observations of herbage mass similar to those of the smaller paddocks, but at a herbage allowance in excess of those of the smaller paddocks.

Thirty beef steers (mean weight $=313 \mathrm{~kg}$ in $1991,267 \mathrm{~kg}$ in 1992) were randomly allocated by weight to groups of 3 head and assigned to an experimental paddock. The steers had been grazing wheat forage for several weeks before trial initiation to preclude variation due to radical change of diet.

In both February 1991 and January 1992, each paddock was continuously stocked with 3 beef steers during the 7-day grazing trial. Wheat was in the same vegetative stage of development during the grazing trial for both years (Feekes stage 5). Forage intake was calculated as the ratio of fecal output and diet indigestibility. Fecal output was estimated using chromic oxide dilution (Pond et al. 1987). Each steer was dosed twice daily (0700 and 1700) with $4 \mathrm{~g}$ of chromic oxide administered orally in a gelatin capsule. Marker administration began 3 days prior to grazing the experimental paddocks and continued through the subsequent 7-day grazing trial. Fecal samples were collected twice daily $(0700$ and 1700 ) on the final 4 days of each 7-day grazing trial. This resulted in a 6-day equilibration period and a 4-day collection period. Although marker recovery was not determined by total fecal collections, previous studies on wheat pasture at this location have demonstrated that this method provided estimates of total fecal output that were not different $(P>0.05)$ from total fecal collections (Vogel et al. 1985). Fecal samples were composited across days within steers, frozen, and dried in a forced air oven to a constant weight. Chromium concentration was determined by atomic absorption spectrophotometry as described by Williams et al. (1962).

Diet indigestibility was determined by in vitro organic matter disappearance of esophageal masticate. Masticate samples were collected from each paddock on days 1 and 3 of the fecal sampling period during each trial. On these days, esophageally fistulated beef steers were fitted with collection bags with plastic liners and allowed to graze each paddock for 15 to $30 \mathrm{~min}$. The beef steers and fistulated steers were not on the test paddocks at the same time. Two steers were used to obtain masticate samples from each paddock. All cattle had been grazing adjacent wheat pastures for a minimum of 8 weeks under identical stocking densities. Forbes and Beattie (1987) have suggested that esophageally fistulated and nonfistulated animals of similar background and nutritional history would not be expected to differ in grazing behavior. Therefore, we assume that the diet samples obtained from the cannulated steers were typical of those selected by the test steers. The cannulated steers had been prepared by licensed veterinarians at the Oklahoma State University College of
Veterinary Medicine and all procedures concerning the fistulated animals had been reviewed by the University Animal Care Committee. Masticate samples were composited across steers within paddocks and across collection days, then frozen and lyophilized. In vitro organic matter disappearance was measured using a modified Tilley and Terry (1963) procedure. Samples were inoculated at $39^{\circ} \mathrm{C}$ for 48 hours in buffered rumen fluid followed by a 24 -hour period in acid-pepsin. The buffer was as described by McDougall (1948), except that urea ( $1 \mathrm{~g} /$ /iter) was added and the $\mathrm{CaCl}_{2}$ was reduced to 0.10 of the specified concentration. Inoculum for the procedure was obtained from rumen cannulated steers grazing wheat forage. Daily gain of beef steers was estimated from forage intake data and net energy values calculated from the organic matter disappearance values of the esophageal masticate samples (NRC 1984). Equations utilized in the net energy calculations are as follows:

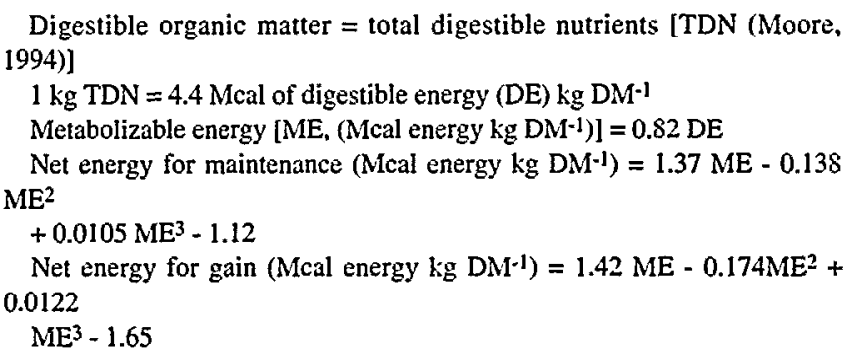

Data from both trials were combined for statistical analysis. Non-linear regression procedures (SAS 1987) were used to fit quadratic models with a plateau function to describe relationships between organic matter disappearance, forage intake, and estimated daily gain for both herbage mass and herbage allowance. Values for herbage mass from the 4 larger paddocks were within the range of the 0.4 ha paddocks, but the herbage allowance was greater than those observed in the other test paddocks due to the larger paddock size. Therefore, the relationships between the dependent variables and herbage mass were evaluated for the full data set $(n=20)$ and a reduced data set $(n=16)$ in which the 4 observations from the larger paddocks were deleted. Critical (value of the independent variable at which the dependent variable reaches a plateau) and plateau (value of the dependent variable at the critical point) values were determined for all models.

\section{Results}

Herbage mass: Ranges of the dependent and independent variables for the full data set are shown in Table 1. Regression and statistics parameters for the relationships of organic matter disappearance, forage intake and estimated daily gain to herbage mass are shown for both the full and reduced data sets in Table 2 . In general, better fits of the data (i.e., higher $r^{2}$ values and lower mean square errors) were obtained with the reduced data set. However, critical values for the dependent variables ranged from 2,670 to $3,073 \mathrm{~kg} / \mathrm{ha}$ and were substantially higher than those (i.e., 1,243 to $1,264 \mathrm{~kg} / \mathrm{ha}$ ) derived from the full data set. We considered the lower values to be more realistic and more consistent with previous observations on pasture. Plateau values for organic matter disappearance, forage intake, and estimated daily gain for the full and reduced data sets were 72.4 and $75.3 \% ; 2.3$ and 2.6 $\mathrm{kg} / 100 \mathrm{~kg} \mathrm{BW} ; 1.0$ and $1.4 \mathrm{~kg}$, respectively. Fecal output $(\mathrm{g} / 100$ $\mathrm{kg} \mathrm{BW}$ ) was not affected by herbage mass. 
Table 1. Ranges of the dependent and independent variables for 7-day forage intake trials using the full data set $(n=20)$ for years 1 and 2.

\begin{tabular}{lccc}
\hline \hline Variable & Minimum & Maximum & Mean \\
\hline Herbage mass, kg/ha & 672 & 2645 & 1256 \\
Daily herbage allowance, $\mathrm{kg} / 100 \mathrm{~kg} \mathrm{BW}$ & 5.5 & 64 & 14.8 \\
Diet in vitra OM disappearance, $\%$ & 62.4 & 77.4 & 70.8 \\
Daily forage intake, kg OM/100 kg BW & 1.5 & 2.9 & 2.2 \\
Estimated daily gain, $\mathrm{kg}$ & 0.1 & 1.4 & 0.86 \\
Fecal output, kg/100 kg BW & 0.54 & 0.73 & 0.63 \\
\hline
\end{tabular}

Herbage allowance: Regression and statistics parameters for relationships of the dependent variables to herbage allowance are shown in Table 2. Diet organic matter disappearance increased with increasing herbage allowance to a critical value of 24.3 $\mathrm{kg} / 100 \mathrm{~kg}$ body weight and reached a plateau at a value of $75.3 \%$. Fecal output ranged from 0.54 to $0.73 \%$ of body weight with a mean fecal output of $0.63 \%$ of body weight and was not influenced by herbage allowance. Conrad et al. (1964) reported that fecal output of lactating dairy cows averaged $1.07 \%$ of body weight and Owens (1991) reported that fecal output of forage-fed cattle ranged from 0.4 to $1.3 \%$ of body weight (mean $=0.83 \%$; $S D=0.2$ ). Forage intake responded to increasing herbage allowance in a manner similar to organic matter disappearance. Peak forage intake of $2.57 \mathrm{~kg} / 100 \mathrm{~kg}$ BW occurred at a herbage allowance of $21.1 \mathrm{~kg} / 100 \mathrm{~kg} \mathrm{BW}$. Estimated daily gain of steers reached a plateau of $1.3 \mathrm{~kg}$ at a herbage allowance of $23.0 \mathrm{~kg} / 100$ $\mathrm{kg}$ body weight.

\section{Discussion}

In vitro organic matter disappearance of wheat forage declined from about $75 \%$ at a herbage mass of $2,670 \mathrm{~kg} / \mathrm{ha}$ to approximately $66 \%$ at a herbage mass of about $700 \mathrm{~kg} / \mathrm{ha}$. Jamieson and Hodgson (1979) reported diet in vitro organic matter disappearance declined in one experiment from 79 to $72 \%$ as a perennial ryegrass sward was progressively defoliated from 2,373 to 1,643 $\mathrm{kg} / \mathrm{ha}$. Ellis et al. (1984) reported that dry matter digestibility by steers grazing annual ryegrass was progressively decreased $(P<0.01)$ as herbage allowance was reduced to less than $30 \mathrm{~kg} / 100$ $\mathrm{kg} \mathrm{BW}$. In the present study, organic matter disappearance declined as herbage allowance fell below $24.3 \mathrm{~kg} / 100 \mathrm{~kg}$ BW.

With regard to forage intake, our data were consistent with the results of previous studies on ryegrass pasture in which forage intake generally reached a plateau at a herbage mass between 1,500 and $3,000 \mathrm{~kg} \mathrm{DM} / \mathrm{ha}$ (Hodgson 1977). With respect to herbage allowance, our results were similar to those reported for annual ryegrass (Ellis et al. 1984, Telford 1980) in which forage intake decreased at herbage allowances of less than $25 \mathrm{~kg} / 100 \mathrm{~kg}$ BW. Recent work on wheat pasture demonstrated that weight gain of steers declined as herbage allowances fell below 24 $\mathrm{kg} / 100 \mathrm{~kg} \mathrm{BW}$ (W.E. Pinchak, unpublished data). Our data, however, suggested a higher herbage allowance plateau than the 10 to $12 \%$ of animal body weight reported by Hodgson (1990).

The range of estimated daily gain for this trial was in agreement with field observations for beef steers grazing wheat forage (Horn et al. 1981, Mader et al. 1983, Horn et al. 1992). The values were greater than those reported by Ellis et al. (1984) in which average daily gains up to $0.8 \mathrm{~kg} / \mathrm{day}$ were noted for steers

Table 2. Regression and statistical parameters for relationships between the dependent variables in vitro organic matter digestiblity, organic matter intake, digestible organic matter intake and estimated daily gain and herbage mass and allowance for both years.

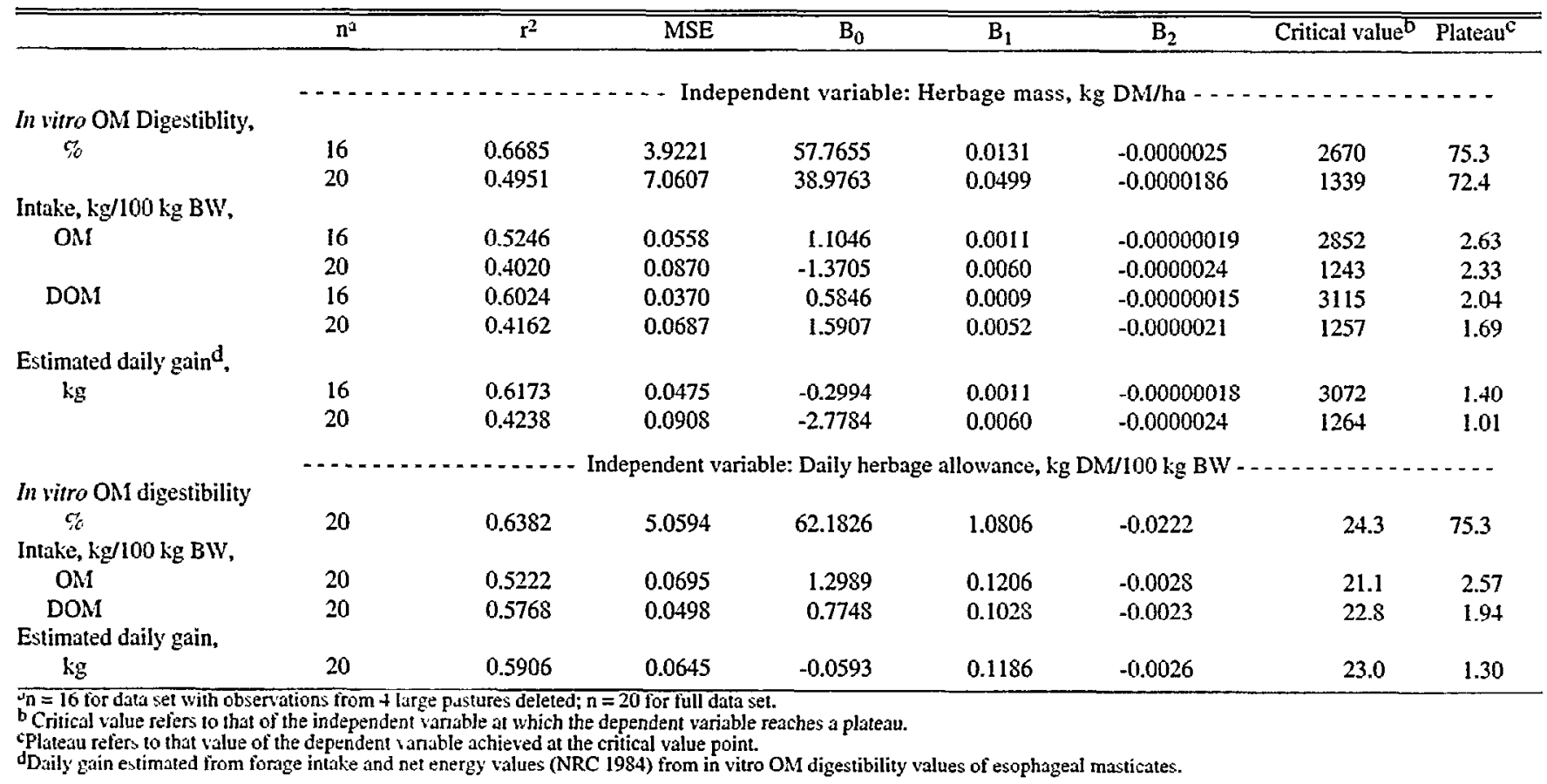


grazing fertilized 'Gulf' ryegrass. Our data also indicated that estimated daily gain of steers grazing wheat forage reached a plateau at a much higher herbage allowance than for steers grazing pastures of tropical forages (Mott 1984). Working with tropical forages, Mott (1984) suggested optimum animal performance occurred at herbage allowance of approximately $5 \mathrm{~kg}$ of DM/100 kg BW.

\section{Conclusions}

The daily herbage allowance encompassed in this study are typical of values encountered in conventional programs for growing beef cattle on winter wheat pasture in the southern Great Plains of the United States. Our results agreed with observations previously reported for cattle grazing annual ryegrass (Ellis et al. 1984, Telford 1980). Our results agree with conclusions of Ellis et al. (1984) who observed that decreased forage intake in response to lower herbage allowance was due to reduced digestibility of forage rather than decreased intake due to inability to prehend forage. The herbage mass at which forage organic matter digestibility. forage intake and estimated daily gain of cattle peaked varied depending on whether or not all pastures were included in the data set. Herbage mass provides no measure of grazing pressure and perhaps at best is useful only as a general descriptor of pastures. In contrast, the relationship of forage intake to herbage allowance as a measure of grazing pressure in this study yielded results similar to those found in the literature. Our data suggests that forage organic matter digestibility, forage intake and estimated daily gain of growing cattle will decline at wheat herbage allowance below 21 to $24 \mathrm{~kg} / 100 \mathrm{~kg}$ BW. These thresholds and factors affecting them need to be defined more clearly to improve management of growing cattle grazing cool-season annual forages.

\section{Literature Cited}

Conrad, H.R., A.D. Pratt, and J.W. Hibbs. 1964. Regulation of feed intake in dairy cows. I. Change in importance of physical and physiological factors with increasing digestibility' J. Dairy Sci. 47:54-62.

Ellis, W.C., J.P. Telford, H. Lippke, and M.W. Riewe. 1984. Forage and grazing effects on intake and utilization of annual ryegrass by cattle. p. 223-234. In: G.W. Hom (ed.) Proc. of the Nat. Wheat Pasture Symposium. Okla. Agr. Exp. Sta. MP-115.

Forbes, T.D.A. and M.M. Beattie. 1987. Comparative studies of ingestive behaviour and diet composition of oesophageal-fistulated and nonfistulated cows and sheep. Grass Forage Sci. 42:79.

Hodgson, J. 1977. Factors limiting herbage intake by the grazing animal. p. 70-75. In: Proc. of the Int. Meeting on Anim. Prod. from Temperate Grassl., Dublin.

Hodgson, John. 1990. Grazing Management: Science into Practice. Longman Sci. \& Tech. and John Wiley' \& Sons, Inc. N.Y.

Horn, G.W., T.L. Mader, S.L. Armbruster, and R.R. Frahm. 1981. Effect of monensin on ruminal fermentution, forage intake, and weight gains of wheat pasture stocker cattle. J. Anim. Sci. 52:447-454.

Horn, G.W., P.A. Beck, M.D. Cravey, D.J. Bernardo, and K.B. Poling. 1992. A self-fed monensin-containing energy supplement for stocker cattle grazing wheat pasture. p. 301-306. Okla. Agr. Exp. Sta. MP-136.

Jamieson, W.S. and J. Hodgson. 1979. The effect of daily herbage allowance and sward characteristics upon the ingestive behaviour and herbage intake of calves under strip-grazıng management. Grass Forage Sci. 34:261-271.
Mader, T.L., G.W. Horn, W.A. Phillips, and R.W. McNew. 1983. Low quality roughages for steers grazing wheat pasture. I. Effect on weight gain and bloat. J. Anim. Sci. 56:1021-1028.

McDougall, E.I. 1948. Studies of ruminal saliva. I. The composition of output of sheep's saliva. Biochem. J. 43:49.

Moore, J.E. 1994. Forage quality indices: Development and Application. p. 974. In: George C. Fahey, Jr. (ed.), Forage Quality, Evaluation, and Utilization. Amer. Society of Agron. Madison, Wis.

Mott, G.O. 1984. Relationship of available forage and animal performance in tropical grazing systems. p. 373-377. In: Proc. of the 1984 Forage and Grassl. Conf. Amer. Forage and Grassl. Counc. Houston, Tex.

NRC. 1984. National Research Council. Nutrient requirements of beef cattle. National Academy Press. Washington, D.C.

Pond, K.R., J.C. Burns, and D.S. Fisher. 1987. External markers - use and methodology in grazing studies. p. 49-53. In: Proc. Grazing Livestock Nutrition Conference, Jackson, Wyo.

Owens, F.N., Juan Garza, and Paula Dubeski. 1991. Advances in amino acid and $N$ nutrition in grazing ruminants. p. 109-137. In F.T. McCollum and M.B. Judkins (ed.) Proceedings of the 2nd Grazing Livestock Nutrition Conference. Okla. Agr. Exp. Sta. MP-133.

SAS Institute, Inc. 1987. SAS/STAT ${ }^{\text {TM }}$ guide for personal computers, 6th ed. Statistical Analysis System Institute, Inc. Cary, N.C.

Telford, James Pat. 1980. Factors affecting intake and digestibility of grazed forage. Ph.D. dissertation. Texas A\&M University, College Station, Tex.

Tilley, J.M.A. and R.A. Terry. 1963. A two-stage technique for the in vitro digestion of forage crops. J. Brit. Grassl. Soc. 18:104.

Vogel, G.J., J. Zorrilla-Rios, G.W. Horn, R.W. McNew, and K.B. Poling. 1985. Comparison of external markers for estimating fecal output of cattle grazing wheat pasture. p. 155-160. Okla. Agr. Exp. Sta. MP-117.

Williams, C.H., D.J. David, and O. Lismaa. 1962. The determination of chromic oxide in feces samples by atomic absorption spectrophotometry. J. Agr. Sci. 59:381. 